\title{
PENGARUH PARTISIPASI PENYUSUNAN ANGGARAN, KEJELASAN SASARAN ANGGARAN, PROFESIONALISME SUMBER DAYA MANUSIA DAN KOMITMEN ORGANISASI TERHADAP KINERJA MANAJERIAL (STUDI KASUS PADA SKPD KABUPATEN PESAWARAN)
}

\author{
Oleh: \\ Ferin Annisa, \\ Email :ferinannisa217@gmail.com \\ Eka Sariningsih \\ Email:ekasariningsih@yahoo.com \\ Muhammad Luthfi \\ Email :mluthfi@malahayati.ac.id
}

Jurusan Akuntansi Program S1 Fakultas Ekonomi

Universitas Malahayati Bandar Lampung Indonesia

\begin{abstract}
.
Managerial Performance, namely the work units of public organizations are expected to create a conducive work environment by integrating the leadership capabilities and abilities of subordinates.

The purpose of this study was to determine how much influence budgeting participation, clarity of budget targets, professionalism of human resources, organizational commitment and work motivation on managerial performance. Data was collected by Purposive Sampling, with a sample of 96 respondents involved in budgeting. The analysis technique used is the Partial Least Square (PLS) model. The test results show that the partial hypothesis of budgeting participation, professionalism of human resources, organizational commitment and work motivation have an influence on managerial performance. While the clarity of the budget target does not affect managerial performance. The result of the determination coefficient test $(R 2)$ is around 0.611.

Keywords: budgeting participation, clarity of budget targets, professionalism of human resources, organizational commitment and work motivation on managerial performance.
\end{abstract}

\section{PENDAHULUAN}

Menurut PP Nomor 58 Tahun 2005, kinerja adalah keluaran atau hasil dari kegiatan/program/ yang akan atau telah dicapai sehubungan dengan penggunaan anggaran dengan kualitas dan kuantitas yang terukur. Kinerja Manajerial yaitu unitunit kerja organisasi publik diharapkan dapat menciptakan lingkungan kerja yang 
kondusif dengan mengintegrasikan kemampuan pimpinan dan kemampuan bawahan. Sebagai organisasi sektor publik, pemerintah daerah dituntut agar memiliki kinerja yang berorientasi pada kepentingan masyarakat dan mendorong pemerintah untuk senantiasa tanggap akan tuntutan lingkungannya, dengan berupaya memberikan pelayanan terbaik secara transparan dan berkualitas serta adanya pembagian tugas yang baik pada pemerintah tersebut. Tuntutan yang semakin tinggi diajukan terhadap pertanggungjawaban yang diberikan oleh penyelenggara negara atas kepercayaan yang diamanatkan kepada mereka (Putri, 2013).

Kinerja pemerintah daerah selama ini masih rendah. Ada beberapa faktor penyebab terjadinya kinerja pemerintah daerah tersebut rendah, diantaranya karena sistem pengelolaan keuangan daerah yang masih lemah dimulai dari proses perencanaan dan penganggaran APBD, pelaksanaan/penatausahaan APBD, pertanggungjawaban yang berupa pelaporan hasil pelaksanaan APBD serta pengawasan.

Laporan Realisasi Anggaran Pendapatan dan Belanja Daerah Pemerintah Kabupaten Pesawaran pada Tahun 2012 dan 2015 mengalami Surplus, jumlah Pendapatan yang terealisasi lebih besar dari jumlah belanja daerah yang terealisasi. Sedangkan di Tahun 2013, 2014 dan 2016 Laporan Realisasi Anggaran dan Belanja Daerah mengalami defisit karena jumlah pendapatan yang terealisasi lebih kecil dari jumlah belanja daerah yang terealisasi.

Tabel Laporan Realisasi Anggaran Pendapatan dan Belanja Daerah Pemerintah Kabupaten Pesawaran tahun Anggaran 2012-2016

\begin{tabular}{|l|c|c|c|}
\hline \multicolumn{1}{|c|}{ Uraian } & \multicolumn{1}{|c|}{$\begin{array}{c}\text { Realisasi } \\
(\mathbf{R p})\end{array}$} & $\begin{array}{c}\text { Surplus/Defisit } \\
(\mathbf{R p})\end{array}$ & Tahun \\
\cline { 1 - 2 } Pendapatan & $676.345 .193 .403,18$ & \multirow{2}{*}{$3.954 .487 .966,18$} & 2012 \\
\cline { 1 - 2 } Belanja Daerah & $672.390 .705 .437,00$ & $(39.983 .818 .649,17)$ & 2013 \\
\cline { 1 - 2 } Pendapatan & $782.447 .803 .025,83$ & & 2014 \\
\hline
\end{tabular}


Jurnal Ilmiah Akuntansi Rahmaniyah (JIAR)

Vol. 3 No.2, Juni 2020, $1-14$

Annisa, Sariningsih, Luthfi

\begin{tabular}{|l|l|l|c|}
\hline Belanja Daerah & $930.780 .038 .473,00$ & & \\
\cline { 1 - 2 } Pendapatan & $948.857 .310 .023,80$ & \multirow{2}{*}{$20.116 .093 .200,80$} & 2015 \\
\cline { 1 - 2 } Belanja Daerah & $928.741 .216 .823,00$ & & \\
\cline { 1 - 2 } Pendapatan & $1.186 .433 .984 .696,55$ & $(26.550 .700 .678,45)$ & 2016 \\
\hline Belanja Daerah & $1.212 .984 .685 .375,00$ & & \\
\hline
\end{tabular}

(Sumber: https://www.pesawarankab.go.id/) Tahun 2017

Penelitian ini merupakan replikasi dari penelitian sebelumnya yaitu Pituriningsih dan Widiastuti (2015) dengan menambah variabel penelitian yaitu komitmen organisasi, yang memiliki hasil bahwa partisipasi penyusunan anggaran berpengaruh positif, kejelasan sasaran anggaran berpengaruh negatif, profesionalisme sumber daya manusia berpengaruh positif, sedangkan pada penelitian Nurhalimah (2013) kejelasan sasaran angaran tidak berpengaruh terhadap kinerja manajerial, penelitian Putra (2013) kejelasan sasaran anggaran berpengaruh positif terhadap kinerja manajerial.

Partisipasi Penyusunan Anggaran, suatu proses dimana para manajer tingkat atas dan bawah terlibat dalam mempersiapkan dan menentukan tujuan anggaran mereka, kemudian manajer dievaluasi dan mendapat imbalan berdasarkan pencapaian anggaran mereka. Partisipasi melibatkan manajer yang lebih bawah dalam penyusunan anggaran dapat menimbulkan rasa tanggung jawab untuk memenuhi target atau sasaran yang telah ditentukan dalam anggaran (Dianawati, 2009).

Kejelasan sasaran anggaran akan membantu pegawai untuk mencapai kinerja yang diharapkan, dimana dengan mengetahui sasaran anggaran tingkat kinerja akan tercapai. Keterlibatan individu akan memahami sasaran yang akan dicapai oleh anggaran tersebut, serta bagaimana akan mencapainya dengan menggunakan sumber yang ada, selanjutnya target-target anggaran yang disusun sesuai dengan yang akan dicapai (Suwandi, 2013).

Suryani (2011) dalam (Pituringsih dan Widiastuty, 2015) mengemukakan bahwa profesionalisme aparat sebagai bentuk dari kemampuan seorang aparat 
dalam menjalankan tugas dan fungsinya secara efektif serta mampu merespon dinamika lingkungan nasional maupun global termasuk perkembangan kebutuhan dan tuntutan masyarakat dengan menciptakan inovasi-inovasi.

Komitmen organisasi suatu tingkat keyakinan sejauh mana seseorang karyawan memihak pada suatu organisasi tertentu yang tujuannya berniat memelihara keanggotaan dalam organisasi itu, Robbins (2008) dalam (Juita, 2013). Motivasi kerja merupakan suatu dorongan, keinginan seseorang dalam melakukan suatu kegiatan atau pekerjaan dengan berpartisipasi aktif, baik waktu maupun biaya demi tercapainya tujuan yang diinginkan Suprianto (2016).

Berdasarkan uraian latar belakang diatas maka peneliti termotivasi untuk melakukan penelitian tentang Kinerja Manajerial "Pengaruh Pastisipasi Penyusunan Anggaran, Kejelasan Sasaran Anggaran, Profesionalisme Sumber Daya Manusia, Komitmen Organisasi dan Motivasi Kerja Terhadap Kinerja Manajerial"

\section{LANDASAN TEORI}

\section{Teori Penetapan Tujuan (Goal Setting Theory)}

Teori ini dikembangkan oleh Locke (1986) dalam (Lubis, 2017). Teori ini menguraikan hubungan antara tujuan yang ditetapkan dan prestasi kerja. Konsep dasar dari teori ini adalah bahwa karyawan yang memahai tujuan (apa yang diharapakan organisasi terhadapnya) akan mempengaruhi perilaku kerjanya.

Beberapa pernyataan yang berkaitan dengan konsep teori penetapan tujuan, yakni tujuan yang sulit menghasilkan prestasi yang lebih tinggi dibanding tujuan yang mudah. Begitu pula dengan tujuan yang spesifik (jelas) dan menantang akan menghasilkan prestasi yang lebih tinggi dibanding tujuan yang bersifat abstrak.

\section{Kinerja Manajerial}

Menurut PP Nomor 58 Tahun 2005, kinerja adalah keluaran atau hasil dari kegiatan/program/ yang akan atau telah dicapai sehubungan dengan penggunaan anggaran dengan kualitas dan kuantitas yang terukur.

Kinerja Manajerial yaitu unit-unit kerja organisasi publik diharapkan dapat menciptakan lingkungan kerja yang kondusif dengan mengintegrasikan 
Jurnal Ilmiah Akuntansi Rahmaniyah (JIAR)

Vol. 3 No.2, Juni 2020, $1-14$

Annisa, Sariningsih, Luthfi

kemampuan pimpinan dan kemampuan bawahan. Sebagai organisasi sektor publik, pemerintah daerah dituntut agar memiliki kinerja yang berorientasi pada kepentingan masyarakat dan mendorong pemerintah untuk senantiasa tanggap akan tuntutan lingkungannya, dengan berupaya memberikan pelayanan terbaik secara transparan dan berkualitas serta adanya pembagian tugas yang baik pada pemerintah tersebut.

Tuntutan yang semakin tinggi diajukan terhadap pertanggungjawaban yang diberikan oleh penyelenggara negara atas kepercayaan yang diamanatkan kepada mereka (Putri, 2013).

\section{Partisipasi Penyusunan Anggaran}

Lubis (2017) Partisipasi adalah suatu proses pengambilan keputusan bersama oleh dua bagian atau lebih pihak dimana keputusan tersebut akan memiliki dampak masa depan terhadap mereka yang membuatnya. Bangun (2009) dalam (Pituringsih dan Widiastuty, 2015) menjelaskan partisipasi sebagai suatu proses pengambilan keputusan bersama oleh dua pihak atau lebih yang mempunyai dampak masa depan bagi pembuat dan penerima keputusan. Partisipasi dalam proses penyusunan anggaran dianggap sebagian orang sebagai obat mujarab untuk memenuhi kebutuhan akan harga diri dan aktualisasi dari para anggota organisasi. Partisipasi adalah suatu proses pengambilan keputusan bersama oleh dua bagian atau lebih pihak dimana keputusan tersebut akan memiliki dampak masa depan terhadap mereka yang membuatnya. Dengan kata lain, pekerja dan manajer tingkat bawah memiliki suara dalam proses manajemen.

\section{Kejelasan Sasaran Anggaran}

Sasaran anggaran adalah target yang dicapai atau hasil yang diharapkan dari suatu program atau kegiatan (Permendagri No. 13/2006). Menurut Suwandi (2013) Anggaran pemerintah daerah yang tertuang dalam APBD adalah rencana kerja keuangan tahunan pemerintah daerah dalam satu tahunnya disusun secara jelas dan spesifik dan merupakan desain teknis pelaksana, strategi untuk mencapai tujuan daerah. 
Anggaran yang baik tidak hanya memuat informasi tentang pendapatan, belanja dan pembiayaan umum, lebih dari itu anggaran harus memberikan informasi mengenai kondisi kinerja pemerintah daerah yang akan dicapai, sehingga anggaran dapat dijadikan tolak ukur pencapaian kinerja dengan kata lain kualitas anggaran daerah dapat menentukan kualitas pelaksanaan fungsi-fungsi pemerintah daerah.

\section{Profesionalisme Sumber Daya Manusia}

Profesionalime yaitu mutu, kualitas, dan tindak tanduk yang merupakan ciri suatu profesi atau orang yang professional Menurut Kamus Besar bahasa Indonesia (KBBI). Sonny Keraf (1998) dalam (Agus dan Ardana, 2018) Profesi adalah pekerjaan yang dilakukan sebagai nafkah hidup dengan mengandalkan keahlian dan keterampilan yang tinggi dan dengan melibatkan komitmen pribadi (moral) yang mendalam.

Dengan demikian orang yang profesional adalah orang yang menekuni pekerjaannya dengan purna-waktu, dan hidup dari pekerjaan itu dengan mengandalkan keahlian dan keterampilan yang tinggi serta mempunyai komitmen pribadi yang mendalam atas pekerjaannya itu.

\section{Komitmen Organisasi}

Komitmen organisasi menurut Juita (2013) adalah suatu tingkat keyakinan sejauh mana seseorang karyawan memihak pada suatu organisasi tertentu yang tujuan nya berniat memelihara keanggotaan dalam organisasi itu.

Komitmen organisasi juga merupakan nilai personal, yang terkadang mengacu pada sikap loyal pada perusahaan atau komitmen pada perusahaan. Komitmen organisasi sering diartikan secara individu dan berhubungan dengan keterlibatan orang tersebut pada organisasi yang bersangkutan (Lubis, 2017)

\section{Motivasi Kerja}

Alma (2011) motivasi adalah kemauan untuk berbuat sesuatu sedangkan motif adalah kebutuhan, keinginan, dorongan atau implus. Motivasi seseorang 
tergantung pada kekuatan motifnya. Motif dengan kekuatan yang sangat besarlah yang akan menentukan prilaku seseorang.

Motivasi kerja merupakan suatu dorongan, keinginan seseorang dalam melakukan suatu kegiatan atau pekerjan dengan berpartisipasi aktif, baik waktu maupun biaya demi tercapainya tujuan yang diinginkan (Suprianto, 2016).

\section{METODELOGI PENELITIAN}

Populasi dalam penelitian ini adalah Satuan Kerja Perangkat Daerah (SKPD) pada dinas kabupaten Pesawaran yang berjumlah 4.205 tenaga kerja. Sampel dalam penelitian ini menggunakan purposive sampling, sampel yang memenuhi syarat dalam penelitian ini yaitu 96 tenaga kerja dari 22 dinas pada kepala bidang, kepala subbagian keuangan, kepala subbagian program, evaluasi dan pelaporan keuangan pada pemerintah daerah kabupaten Pesawaran.

\section{Definisi Operasional Variabel}

\section{Kinerja Manajerial}

Instrumen yang digunakan untuk mengukur kinerja Manajerial terdiri dari 8 (tujuh) pertanyaan yang dikembangkan oleh Sitepu (2017). Diukur dengan indikator Capaian atau target kinerja, Analisis standar belanja, Standar satuan harga, Standar pelayanan minimal.

\section{Partisipasi Penyusunan Anggaran}

Instrumen yang digunakan untuk mengukur partisipasi penyusunan anggaran terdiri dari 7 (tujuh) pernyataan yang dikembangkan oleh Sitepu (2017), dengan indikator Keterlibatan manajer dalam proses penyusunan anggaran, Alasan atasan dalam merevisi anggaran yang diusulkan, Frekuensi pemberian saran dan pendapat, Pengaruh manajer dalam anggaran akhir, Pentingnya kontribusi yang diberikan, Frekuensi penyampaian pendapat.

\section{Kejelasan Sasaran Anggaran}

Instrumen yang digunakan untuk mengukur kejelasan sasaran anggaran terdiri dari 5 (lima) pernyataan yang dikembangkan oleh Sitepu (2017). Variabel ini diukur dengan indikator Kejelasan sasaran, Konsekuensi, Pemahaman sasaran, Ketidakjelasan sasaran. 


\section{Profesionalisme Sumber Daya Manusia}

Instrumen yang digunakan untuk mengukur profesionalisme sumber daya manusia terdiri dari 5 (lima) pernyataan yang dikembangkan Adri (2017), dengan indikator Pengabdian pada profesi, Kewajiban social, Kemandirian, Keyakinan terhadap peraturan profesi, Hubungan dengan sesama profesi.

\section{Komitmen Organisasi}

Instrumen yang digunakan untuk mengukur komitemen organisasi terdiri dari 5 (lima) pernyataan yang dikembangkan Ulfa (2017), dengan indikator Kemauan karyawan, Kesetiaan karyawan, Kebanggaan karyawan terhadap organisasi.

\section{Motivasi Kerja}

Instrumen yang digunakan untuk mengukur komitemen organisasi terdiri dari 5 (lima) pernyataan yang dikembangkan Ulfa (2017), dengan indikator Tanggung Jawab dalam melaksanakan tugas, Melaksanakan tugas dengan target yang jelas, Memiliki tujuan yang jelas dan menantang, Ada umpan balik atas hasil pekerjaannya, Memiliki rasa senang dalam bekerja, Selalu berusaha mengungguli orang lain, Diutamakan prestasi dari apa yang dikerjakannya.

\section{HASIL DAN PEMBAHASAN}

\section{Outer Model}

\section{A. Uji Validitas}

Sebuah instrumen dikatakan valid jika mampu mengukur apa yang diinginkan dapat mengungkapkan data dari variable yang diteliti secara tepat. Berdasarkan data yang diolah SmartPLS 3.0 dinyatakan memiliki validitas yang baik karena nilai loading factor diatas 0.70 (Ghozali, 2015).

1. AVE

\begin{tabular}{|l|l|}
\hline Variabel & Average Variance Extracted (AVE \\
\hline Partisipasi Penyusunan Anggaran & 0.585 \\
\hline Kejelasan Sasaran Anggaran & 0.520 \\
\hline Profesionalisme Sumber Daya Manusia & 0.595 \\
\hline Komitmen Organisasi & 0.701 \\
\hline Motivasi Kerja & 0.509 \\
\hline
\end{tabular}

Sumber : Data diolah 2018 
Hasil dalam validitas convergent dihitung dengan melihat output construct reliability and validity yang didalamnya terdapat nilai AVE. Berdasarkan pengujian masing-masing variabel memiliki nilai diatas 0,5. Hal ini dapat diartikan bahwa konstrak memiliki nilai convergent yang baik.

\section{Validitas Diskriminan}

Kriteria cross loading dikatakan memiliki discriminant validity yang baik apabila korelasi antara konstrak dengan indikatornya lebih tinggi daripada korelasi dengan indikator dari konstrak blok lainnya. Berdasarkan pengujian menggunakan SmartPLS 3.0 korelasi antara konstrak dengan indikator variabel satu lebih tinggi dari pada korelasi dengan indikator dari kontrak variabel lain, begitu seterusnya, hal ini menunjukkan bahwa data memiliki validitas diskriminan yang baik.

\section{Perbandingan Nilai Kuadrat Korelasi}

Untuk melihat discriminant validity yang baik adalah dengan melakukan perbandingan. Perbandingan dilakukan dengan membandingkan antara nilai kuadrat korelasi antara kontrak dengan nilai AVE atau korelasi antara konstrak dengan akar AVE. Berdasarkan tabel nilai AVE tidak melebihi nilai akar AVE, hal ini menunjukkan bahwa data memiliki validitas diskriminan yang baik.

\section{B. Uji Reliabilitas}

Pemeriksaan reliabilitas konstrak dengan melihat output construct reliability and validity yang didalamnya terdapat hasil output composite reliability dan cronbach's alpha. Dikatakan reliabel jika nilai lebih dari 0.70. Berdasarkan tabel data dinyatakan reliabel karena nilai composite reliability dan cronbach's alpha diatas 0.70 .

\section{Inner Model}

\section{A. Coefficient Determination ( $\mathbf{R}^{2}$ )}

Konstrak endogen diuji untuk menguatkan antara konstrak eksogen dengan mengevaluasi $\mathrm{R}^{2}$. Berdasarkan tabel 4.10 menunjukkan bahwa nilai $\mathrm{R}^{2}$ kinerja manajerial adalah 0.611. Artinya konstrak partisipasi penyusunan anggaran, 
kejelasan sasaran anggaran, profesionalisme sumber daya manusia, komitmen organisasi dan motivasi kerja mampu berkontribusi dan menjelaskan variabel konstrak kinerja manajerisl sebesar $61.1 \%$, sisanya $38.9 \%$ diterangkan oleh konstrak lainnya diluar yang diteliti.

\section{B. Path Coefficient}

Pengujian path coefficient digunakan untuk meyakinkan bahwa hubungan antar konstrak adalah kuat. Pada original sample hubungan antar konstrak dikatakan kuat jika path coefficient tersebut lebih besar dari 0.100, selanjutnya dikatakan signifikan jika path coefficient 0.050 pada $\mathrm{T}$ statistic. Partisipasi penyusunan anggaran menunjukkan nilai original sampel 0.216 , profesionalisme sumber daya manusia 0.449 dan komitmen organisasi dengan nilai 0.121 , sedangkan kejelasan sasaran anggaran dengan nilai original sample -0.051 atau kurang dari 0.100 .

\begin{tabular}{|l|l|l|}
\hline Variabel & Original Sample (O) & T Statistics \\
\hline Partisipasi Penyusunan Anggaran & 0.216 & $2.801^{* * *}$ \\
\hline Kejelasan Sasaran Anggaran & -0.051 & 0.300 \\
\hline Profesionalisme Sumber Daya Manusia & 0.449 & $2.960^{* * *}$ \\
\hline Komitmen Organisasi & 0.121 & 1.230 \\
\hline Motivasi Kerja & 0.196 & $2.081^{* *}$ \\
\hline
\end{tabular}

Sumber : Data diolah 2018

\section{Pengujian Hipotesis}

Diperoleh bahwa variabel partisipasi penyusunan anggaran, profesionalisme sumber daya manusia dan komitmen organisasi memiliki arah positif sedangkan kejelasan sasaran anggaran memiliki arah yang negatif. Hal ini berarti bahwa semakin tinggi partisipasi penyusunan anggaran, profesionalisme sumber daya manusia, komitmen organisasi dan motivasi kerja maka semakin tinggi pula kinerja manajerial yang akan dihasilkan.

\section{Pembahasan}

\section{Partisipasi Penyusunan Anggaran terhadap Kinerja Manajerial}

Berdasarkan hasil uji terhadap koefisien parameter antara partisipasi penyusunan anggaran terhadap kinerja manajerial menunjukkan adanya pengaruh positif pada nilai 0,216 , dengan nilai $\mathrm{T}_{\text {statistik }} 2,081$. Hipotesis pertama dapat 
diterima atau berpengaruh sangat signifikan positif terhadap kinerja manajerial, hal ini menunjukkan partisipasi penyusunan anggaran mempengaruhi tingkat kinerja manajerial yang berarti bahwa semakin tinggi tingkat keterlibatan dalam proses penyusunan anggaran maka semakin tinggi pula kinerja manajerial yang akan dihasilkan.

\section{Kejelasan Sasaran Anggaran terhadap Kinerja Manajerial}

Hasil uji terhadap koefisien parameter antara kejelasan sasaran anggaran terhadap kinerja manajerial menunjukkan adanya pengaruh positif pada nilai 0,051, dengan nilai $\mathrm{T}_{\text {statistik }}$ 0,290. Dengan demikian hipotesis kedua dapat dikatakan tidak berpengaruh terhadap kinerja manajerial, karena nilai $\mathrm{T}_{\text {statistik tidak }}$ menunjukkan pada kriteria nilai signifikansi. Sehingga dapat diambil kesimpulan bahwa kejelasan sasaran anggaran tidak berpengaruh terhadap kinerja manajerial.

\section{Profesionalisme Sumber Daya Manusia terhadap Kinerja Manajerial}

Hasil uji terhadap koefisien parameter antara profesionalisme sumber daya manusia terhadap kinerja manajerial menunjukkan adanya pengaruh positif pada nilai 0,449 , dengan nilai $\mathrm{T}_{\text {statistik }}$ 2,960. Dengan demikian hipotesis ketiga dapat diterima, yang berarti profesionalisme sumber daya manusia berpengaruh sangat signifikan positif terhadap kinerja manajerial, hal ini menunjukkan bahwa profesionalisme sumber daya manusia mempengaruhi tingkat kinerja manajerial yang berarti semakin tinggi profesionalisme sumber daya manusia yang dimiliki maka semakin tinggi pula kinerja manajerial yang akan dihasilkan.

\section{Komitmen Organisasi terhadap Kinerja Manajerial}

Hasil uji terhadap koefisien parameter antara komitmen organisasi terhadap kinerja manajerial menunjukkan adanya pengaruh positif pada nilai 0,121 , dengan nilai t statistik 1,230. Dengan demikian hipotesis keempat dapat diterima atau berpengaruh positif terhadap kinerja manajerial, hal ini menunjukkan bahwa komitmen organisasi mempengaruhi tingkat kinerja manajerial yang berarti semakin tinggi komitmen organisasi yang dimiliki maka semakin tinggi pula kinerja manajerial yang akan dihasilkan. 


\section{Motivasi Kerja terhadap Kinerja Manajerial}

Hasil uji terhadap koefisien parameter antara motivasi kerja terhadap kinerja manajerial menunjukan adanya pengaruh positif pada nilai 0,196 , dengan nilai $\mathrm{T}_{\text {statistik }}$ 2,081. Dengan demikian hipotesis kelima dapat diterima, yang berarti motivasi kerja berpengaruh signifikan positif terhadap kinerja manajerial, hal ini menunjukkan bahwa motivasi kerja mempengaruhi tingkat kinerja manajerial yang berarti semakin tinggi motivasi kerja yang dimiliki maka semakin tinggi pula kinerja manajerial yang akan dihasilkan.

\section{Simpulan dan Saran}

Berdasarkan hasil penelitian partisipasi penyusunan anggaran berpengaruh signifikan positif terhadap kinerja manajerial, kejelasan sasaran anggaran tidak berpengaruh terhadap kinerja manajerial, profesionalisme sumber daya manusia berpengaruh signifikan positif terhadap kinerja manajerial, komitmen organisasi berpengaruh positif terhadap kinerja manajerial dan motivasi kerja berpengaruh positif terhadap kinerja manajerial. Penelitian selanjutnya diharapkan dapat menambah variabel independen dalam penelitian mengenai kinerja manajerial seperti akuntabilitas publik, sistem pengendalian intern pemerintah, desentralisasi.

\section{Daftar Pustaka}

Adri, Abdullah. 2017. Pengaruh Profesionalisme dan Komitmen Organisasi terhadap Kinerja Pegawai pada Kanto Inspektorat Provinsi Sumatera Utara. Skripsi. UIN Alauddin Makasar

Agoes, Sukrisno dan Ardana, I Cenik. 2018. Etika Bisnis dan Profesi. Edisi Revisi. Jakarta: Salemba Empat

Alma, Buchari. 2011. Kewirausahaan. Edisi Revisi. Bandung: Alfabeta

Andriani, Durri. Dkk. 2011. Metode Penelitian. Jakarta: Universitas Terbuka

Azmi, Gunawan. Dkk. 2014. Pengaruh Kejelasan Sasaran Anggaran, Kualitas Sumber Daya Manusia, dan Komitmen Organisasi terhadap Kinerja Pengelolaan Keuangan Daerah di Lingkungan Pemerintah Aceh. Jurnal Magister Akuntansi. Pascasarjana Universitas Syiah Kuala. Vol.3,No.4 
Ghozali, Imam. 2008. Structural Equation Modeling Metode Alternative dengan Partial Least Square (PLS). Semarang: Badan Penerbit Universitas Diponegoro.

Juita, Suci Derma. 2013. Pengaruh Kualitas Sumber Daya Manusia, Komitmen Organisasi, dan Komunikasi Organisasi terhadap Kinerja SKPD. Univeristas Negeri Padang

Kusuma, Budi Hartono. 2016. Pengaruh Partisipasi Penyusunan Anggaran terhadap Kinerja Manajerial: Komitmen Organisasi sebagai Variabel Mediasi. Jurnal Akuntansi. Vol.8,No.2.

Lubis, Arfan Ikhsan. 2017. Akuntansi Keperilakuan. Edisi Ketiga, Jakarta: Salemba Empat.

Muhyiddin, Nurlina T. Dkk. 2017 Metodologi Penelitian Ekonomi dan Bisnis. Jakarta: Salemba Empat.

Nordiawan, Dedi. Dkk. 2012. Akuntansi Pemerintahan. Jakarta: Salemba Empat.

Nurhalimah, dkk. 2013. Pengaruh Partisipasi Penyusunan Anggaran, dan Kejelasan sasaran Anggaran terhadap Kinerja Aparatur Pemerintah Daerah di Pemerintah Aceh. Jurnal Akuntansi Vol.02.No.1.

Pituriningsih, Endar. Dan Widiastuty, Erna. 2015. Pengaruh Pastisipasi Penyusunan Anggaran, Kejelasan Sasaran Anggaran, dan Profesionalisme Sumber Daya Manusia terhadap Kinerja Manajerial (SKPD Provinsi Nusa Tenggara Barat). Jurnal Assets, Vol. 5, No.1.

Putra, Deki. 2013. Pengaruh Akuntabilitas Publik dan Kejelasan Sasaran Anggaran Terhadap Kinerja Manajerial Satuan Kerja Perangkat Daerah (Studi Empiris pada SKPD Kota Padang). Jurnal: Universitas Negeri Padang.

Putri, Gustika Yolanda. 2013. Pengaruh Komitmen Organisasi dan Sistem Pengendalian Intern Pemerintah (SPIP). Jurnal: Universitas Negeri Padang

Putri, Natalia Dewinda. 2010. Pengaruh Komitmen Organisasional dan Peran Manajer Pengelolaan Keuangan Daerah terhadap Kinerja Manajerial SKPD (Studi pada Kabupaten Tegal). Skripsi. Universitas Diponegoro Semarang.

Rusmana, Oman. Dkk. 2017. Akuntansi Pemerintahan Daerah. Buku Satu, Jakarta: Salemba Empat.

Sitepu, Ofalyn Octarya. 2017. Kuesioner Pengaruh Partisipasi Penyusunan Anggaran, Kejelasan Sasaran Anggaran, Akuntabilitas Publik, dan 
Pengendalian Akuntansi terhadap Kinerja Manajerial di Inspektorat Pemerintah Provinsi Sumatera Utara. Universitas Sumatera Utara.

Sugiyono. 2014. Metode Penelitian Bisnis Pendekatan Kuantitatif, Kualitatif dan $R D$. Bandung: Alfabeta

Suprianto, Agus. 2016. Pengaruh Desentralisasi, Partisipasi Anggaran, Komitmen Organisasi dan Motivasi Kerja terhadap Kinerja Manajerial SKPD Kabupaten KarangAnyar. Jurnal Ekonomi dan Bisnis. Universitas Muhammadiyah Surakarta.

Suwandi, Annisa Pratiwy. 2013. Pengaruh Kejelasaan Sasaran Anggaran dan Desentralisasi Terhadap Kinerja Pemerintah Daerah (Studi Empiris pada SKPD kota Padang). Jurnal. Univeritas Negeri Padang.

Ulfa, Yustia. 2017. Pengaruh Budaya Organisasi, Komitmen Organisasi, Pengendalian Internal dan Motivasi Kerja terhadap Kinerja Pegawai pada Bea Cukai Tipe Madya belawan. Skripsi. Universitas Sumatera Utara.

Wahjono, Sentot Imam. 2017. Manajemen Sumber Daya Manusia. Jakarta: Salemba Empat

Yamin, Sofyan dan Kurniawan, Heri. 2011. Partial Least Square Path Modeling Aplikasi dengan Software XLSTAT, Smart PLS, dan Visual PLS. Jakarta: Salemba infotek.

Google :

https://www.pesawarankab.go.id/

https://www.saibumi.com/

https://www.kamusbesarbahasaindonesiaonline.com/ 